\title{
Towards an Aesthetics of ELT
}

\author{
Alan Maley \\ doi:10.7575/aiac.alls.v.1n.1p.4
}

\section{Introduction}

One of the major intentions for this paper is to counter the currently prevailing, so-called 'scientific', approach to language learning, with its emphasis on objectives, detailed curricular prescription, predictable outcomes, testing and assessment, bureaucratic control, and the rest. I wish to contrast such 'scientific' approaches unfavourably with intuitive/aesthetic approaches.

As Eisner has pointed out in relation to the factory and assembly-line metaphor of education,

\footnotetext{
Such an image of education requires that schools be organised to prescribe, control, and predict the consequences of their actions, that those consequences be immediate and empirically manifest and that they be measurable. (Eisner 1985, pp.356-7)
}

\section{The current ethos}

We live in a culture of measurement. We stand against the yardstick and are sanctioned if found wanting. Witness the commercial and ideological success of ETS Princeton, Cambridge Exams, the ubiquity of TOEFL, TOIEC, IELTS, etc. etc. Not to speak of the stranglehold which tests and exams have over the state educational apparatus virtually everywhere in the world. 
This is, of course, only one aspect of the wider world of targets (the UK Health Service, Child Benefits scheme, Education Service, etc. are all suffocated by a plethora of often-changing regulation which no human organisation is capable of handling), of benchmarks, of regulation, of assessment, of standards, and of misguided trust in the authorities and in experts. The key features of the current paradigm can be summarized thus:

- It defines Expectations (objectives) and does not create Expectancy.

- It breeds Dependency:

does not stimulate Independence.

- It seeks Predictability:

does not exploit Unpredictability.

- It values Security over Risk

- It promotes Conformity:

does not relish Diversity.

- It pre-empts 'Wonder':

does not stimulate Curiosity/Inquiry.

- It focuses on what is Taught:

not on what is Learnt.

- It seeks to Control:

does not seek to Liberate.

- It is more concerned with Testing, than it is with Teaching / Learning.

Most of these distinctions need no further explanation but I need to gloss at least some of them. 
The distinction between Expectations and Expectancy, is for me an important one. A pedagogy of expectations offers predictable routines and outcomes. Everyone knows what to expect and what is expected of them. This hardly fosters the excitement and involvement in learning which comes from being in a state of expectancy, where teachers and learners alike are in discovery mode, and where unpredictability is embraced rather than avoided. In a recent series of articles in the IATEFL Teacher Development SIG, Adrian Underhill explores precisely this process of teacher improvisation in the moment (Underhill 2008).

This exclusive focus on results, without consideration of how they are attained, leads inevitably to the suppression of wonder, inquiry and curiosity. The combination of these, for me at least, negative characteristics (Expectations, Dependency, Predictability, Security) leads to a culture of conformity which gives the illusion of control over the learning process. There is an unvalidated equation made between what is taught and what is learnt. This is a culture where testing has taken over from teaching concerned with genuine learning.

\section{Some features of teaching, learning and testing}

In this world of predictable outcomes, planning and control it may be helpful to rehearse some basic, elementary truths about the difference between teaching and learning.

- Teaching is a public act. Learning is a private act.

The teacher enacts her role on a public stage and can be seen. What goes on in learners' heads as a result of this activity is a private, largely unknowable process. 
- Teaching is observable. Learning is unobservable

So what the teacher does is observable both by learners and possibly by other monitors, and the teacher is usually held accountable for it. It is not possible to observe learning taking place. It can only be adduced retrospectively, after it has taken place.

- Teaching is an activity. Learning is a process.

Teachers do things in the hope that learning may take place, whereas learning is a process which proceeds at its own rate almost irrespective of what the teacher does.

- Teaching is intermittent. Learning is continuous.

Teaching takes place at spaced intervals: so many hours per week, so many weeks per year, etc. This intermittent activity may only rarely coincide with the continuous (or possibly erratic) processes going on inside learners.

- Teaching is intentional. Learning is unconscious.

The teacher acts with intentions which are not necessarily shared by learners. Much of what they eventually learn may have no more than a tenuous relationship with the teacher's intentions. Learners frequently fail to learn what teachers teach but may also learn many things that the teacher did not teach at all. 
- Teaching is predictable or is often based on the assumption that it is. Learning is unpredictable.

This goes to the heart of the issue. Administrators and experts make curricula, Textbook writers produce highly-structured artefacts. Teachers make lesson plans. These actions are predicated on the assumption that they can predict what learners will learn. (This is part of what Prabhu has referred to elsewhere in this volume as the activities of a largely self-appointed 'priesthood.') Such actions offer the comforting sense that things are under control and that everyone knows what they are doing, and that what they are doing is right. Unfortunately for them, this is rarely the case.

It is also easy to forget that every classroom event is: unrepeatable, unobservable, unpredictable, and has unforeseen long-term effects (Norman Whitney, personal communication). This too undermines any attempt to control the learning process in the ways beloved of educational authorities world-wide.

The teaching/testing nexus also deserves closer scrutiny. By way of introduction let me offer a quotation, the author of which will be revealed in due course.

The worst canker in our school system is the examinations. Everything is arranged with a view to examinations; the parents, the children, and unfortunately also a number of the teachers care for nothing but the results attained in the examinations...poor pay and long hours, too naturally lead to a teacher's looking merely to examination results. 
There are essential differences between a classroom dedicated to real teaching and learning and one overshadowed by tests and examinations. The examinationdominated classroom tends to spread a culture of failure, or fear of failure. It concentrates on eliminating perceived weaknesses rather than on building on learners' strengths. It breeds negative attitudes to what is being learned and, through excess of competitive spirit, to others in the group. Learning is assessed by marks rather than by genuine achievement. It is assumed that 'knowledge' can be 'injected' into the learners in gobbets, in contradistinction to a class where knowledge is seamlessly infectious, and where 'Flow' (Csikszentmihalyi, 1997) the experience of being carried along through 'effortless effort' - is a characteristic feature of the learning experience. Over-emphasis on assessment and testing is certainly inimical to the good-humoured, relaxed, playful atmosphere (Cook, 2000; Huizinga, 1938; Nachmanovitch, 1990) of a class dedicated to cooperative learning. As Timothy Gallwey remarks in perhaps one of the wisest books on learning ever published,

...it doesn't really make sense to measure ourselves in comparison with other immeasurable beings. In fact, we are what we are; we are not how well we happen to perform at a given moment. The grade on a report card may measure an ability in arithmetic (or grammar!), but it doesn't measure the person's value. (Gallwey, 1974, p.100)

And to teach in another way by no means undermines examination results anyway. Otto Jespersen, in 1904 (the author of the earlier quote on examinations!) wrote, 
Teach in the right way, then there will be life and love in it all, and when the examination comes your pupils will know more than if your teaching from the very beginning had been fettered by examination requirements. (Otto Jespersen, 1904, p.9)

I am not, of course, suggesting that we never need to assess progress among our students. But I am contesting the value of a system where the examination is the be-all and end-all of everything, and where the format of the test may be a greater obstacle to learning than the language itself. In short, we need to ensure that the testing tail does not wag the learning dog. What testing and examinations do best is to confirm the power of teachers, administrators and others over those who are the passive (or resisting) recipients of teaching: the learners.

\section{So what is wrong with the prevailing ethos?}

Why should we be concerned about the current strait-jacket of objectives, targets, tests and all the rest outlined above? The major reason is that this nexus of factors is profoundly anti-educational for the following reasons:

$\sim$ It implies an Engineering metaphor for learning. The assumption is that, if all the parts are properly tooled and calibrated, learning will take place smoothly rather like a well-oiled machine. It is however, widely agreed that learning does not happen like this: it is untidy, largely unpredictable and resembles plant growth rather than mechanical precision. A horticultural metaphor would be more appropriate.

$\sim$ It assumes that an atomistic reduction of the key elements to be learned in the teaching stage will lead to an ability to recombine them at the using stage. 
But in complex systems such as language, the whole is more than the mere sum of the parts. A more holistic approach is more desirable therefore.

$\sim$ It usually has an exclusively intellect-focus, with scant attention paid to the affective dimension. This ultimately has deleterious results on the future development of students, who emerge from the process emotionally diminished or stunted.

$\sim$ It is typical of what Paolo Freire (1970) terms a 'Banking' concept of education. Students work to earn grades, credits of knowledge and skills, which they put in their knowledge bank ready to cash in at the test or the examination. This tends to lead to shallow rather than deep processing, (Craik and Lockhart, 1972) and to less enduring learning.

$\sim$ It assumes that it is possible to predict (in the case of foreign language learning) which items of grammar and lexis, which socio-pragmatic contexts, and what content it will be useful for learners to acquire. Yet most syllabus and materials designers are well aware that this is virtually impossible to determine.

$\sim$ Even if it were possible to predict in this way, it is unwarranted to assume that teaching Input $=$ learning Intake. In this view, it is axiomatic that what is taught is what is learnt. Yet SLA research over the past 20 years or more conclusively shows this not to be the case. 
$\sim$ It assumes that everyone in a learning group will progress at roughly the same rate; hence a 'Lockstep' approach to teaching is maintained, whereas learner differences are the rule not the exception, and need to be acknowledged.

$\sim$ It breeds a culture of failure and waste. The winners (in terms of the prevailing ethos) succeed and are rewarded; the rest are consigned to the waste-bin of society, with little or no consideration of the benefits they could confer given the opportunity.

$\sim$ It embodies a top-down philosophy, where one group of people decides unilaterally what is 'good for' another group. The focus is on 'delivery systems' and results rather than on long-term integrated learning.

$\sim$ Above all, it is administratively convenient. In an age of cost-benefit analysis, efficiency, speed and accountability, this should come as no surprise. It is convenient for educational authorities to opt for an approach which offers instant measures of progress, and which has the appearance of rigour and discipline, however flawed it may be in fact.

\section{What is the alternative?}

I am arguing that, if we are truly interested in our learners engaging as 'whole persons' with the process of learning, we need a radically different approach. I have chosen to call this an Aesthetic Approach. Given the relative vagueness of 
the terms 'art' and 'artistry', it seemed useful to list a number of keywords relating to these notions. Here is a preliminary list:

flow balance playfulness creativity elegance harmony joy co-creation
choice sensuality risk deep-processing discovery (aaaah!) openness humour
space physicality curiosity relaxed energy economy cooperation
independence visualization personal commitment story mutual-esteem
non-judgmental engagement trust self-esteem confidence tolerance

Complex notions like art and artistry defy easy definition. That is why I have preferred to draw on Wittgenstein's idea of 'family resemblances' (Wittgenstein, 1963). In any instance of art or artistry we will not find all these qualities present - but the overall pattern of instances will bring them all into play at one time or another. I am arguing that teaching/learning practices which aim to foster these qualities will also be characterised by more effective and more durable acquisition.

\section{Support for the Aesthetic Approach}

There is already much support, theoretical and practical, for what I would term art and artistry in education, some from ELT and some from outside it. We can note work in philosophy and education in general, in the domain of applied linguistics, in feeder fields such as drama, and in the area of practical pedagogical application in ELT itself. Space does not allow a detailed discussion but I would suggest the following form an impressive body of support for an aesthetics of ELT. 
- Philosophy of education:

The work of William James (1962), Ernst Weber, John Dewey and Carl Rogers (1962) all powerfully support an aesthetic vision for education.

The teacher doesn't use words like a writer but like an improviser. The educator is like a creative artist, speaker actor or rather - a spontaneous poet who has to create both text and style of presentation in one and the same moment. (Weber, 1907, p.233)

The hostility to association of fine art with normal processes of living is a pathetic, even a tragic, commentary on life as it is ordinarily lived. Only because that life is usually so stunted, aborted, slack or heavy laden, is the idea entertained that there is some inherent antagonism between the process of normal living and creation and enjoyment of works of aesthetic art. (Dewey, 1980, p.50)

More recently, Elliot Eisner (1985), Seymour Sarasan (1999), Lawrence Stenhouse (1985 ), Parker Palmer (1998), Gordon Allport (1983), Jerome Bruner (1991, 1996), Louis Rubin (1985), Hans Hunfeld (1990), and Peter Lutzker (2007) have reinforced this view of education.

...efficiency is largely a virtue for the tasks we don't like to do; few of us like to eat a great meal efficiently, or to participate in a wonderful conversation efficiently, or indeed to make love efficiently. What we enjoy the most, we linger over. A school system designed with an overriding commitment to efficiency may produce outcomes that have little enduring quality. Children, like the rest of us, seldom voluntarily pursue activities for which they receive little or no satisfaction. Experiencing the aesthetic in the context of intellectual and artistic work is a source of pleasure that predicts best what students are likely to do when they can do whatever they would like to do. (Eisner, 2002, p.xiii) 
Through the artistry of the teacher, the learner acquires a knowledge which is not teachable, but only learnable. (Lutzker, 2007, p.17)

Teachers have been taught that teaching is instrumental but improving education is not about improving teaching as a delivery system. (Stenhouse, 1985, p.110)

Like it or not, and some do not like it, the teacher as performing artist is faced with a terribly complex and difficult task that all those in the conventional performing arts confront: how do you put yourself into a role and then enact it in ways that instruct and move an audience, fulfilling the expectation of the audience that they have in some way learned something about themselves and their world? (Rubin, 1985, p.54)

- General educational dissenters

The notion that schools and classes as currently constituted are both natural and beneficial was subjected to serious questioning in the 1960's and 70's. We appear to have forgotten some of the seminal work done at that time by Everett Reimer: School is Dead (1972), Ivan Illich: De-schooling Society (1973), Paulo Freire: Pedagogy of the Oppressed (1970), Paul Goodman: Compulsory Mis-education (1966), John Holt: How Children Fail (1964) and The Underachieving School (2005), Sybil Marshall: An Experiment in Education, (1970), Sylvia AshtonWarner: Teacher (1986), and Charles Weingartner and Neil Postman: Teaching as a Subversive Activity (1976).

These books expound views now regarded by many as impossibly eccentric and impractical. Yet doubts about the suitability of schools for the promotion of learning obstinately linger. It may well be true that schools are less a place to learn and more a rite of passage, or what Paul Goodman calls 'a mass 
superstition', a mode of manipulation of society to keep it under control during its formative years - to socialize its members into the belief that schools are natural, beneficial and neutral institutions. Education, the inculcation of knowledge and skills, is widely acknowledged to be only a small part of what schools function to provide. Much more important are their functions as providers of custodial care, of indoctrination into conformity with the norms of society and a social role selectors - deciding where children belong in the pecking-order of society. It is perhaps no accident that schools as public institutions came into being alongside industrial mass production in the $19^{\text {th }}$ century, and the production-line mentality is well-embedded.

And it is increasingly acknowledged too that in the post-modern world (and maybe well before that) most learning takes place outside school - at home, between peers and through publicly available sources such as TV and the Internet. (Fulgham, 1986) What is certain is that the teaching of foreign languages in schools is not the only way to learn them, and in all probability not the most effective way either.

\section{- Feeder fields.}

The work of writers from fields peripheral to language learning, offers important lateral views on the issue of learning. Work in drama and theatre - Dorothy Heathcote (Wagner,1979) and Patsy Rodenburg (1992), the arts in general, creativity theory Koestler (1964), Storr (1991), Czikszentmihalyi (1996), personal development models and applied psychology :Timothy Gallwey (1986), 
Mihalyi Csikszentmihaly (1990), Howard Gardner (1985), Donald Schon (1987), Stephen Nakmanovitch (1990), Daniel Goleman (1996).

- Applied linguistics

Both Jakobson (1960) and Jespersen (1904) promoted the idea of an aesthetic approach with atmosphere and attitude at its centre. More recently, Arnold (1999), Cook (2000), Carter (2004), Crystal (1998), Freeman (2000), Widdowson (2000) and others have also supported a more affect-related, playful, artistic view of language teaching and learning.

\section{- ELT practitioners}

Here too there are abundant examples of those uncomfortable with an excessively product-oriented approach to ELT. Space does not allow me to do justice to them all but the work of Mario Rinvolucri (1988, 2005), Jill Hadfield (1992), Bernard Dufeu (1994), Andrew Wright (2008), Alan Maley $(2000,2005,2007)$ and Brian Tomlinson $(1998,2003)$ are among the many practitioners to have offered an alternative view to the currently prevailing one. The notion of what I am calling an aesthetic approach also chimes well with Co-operative Learning (Richards and Rodgers, 2001), with the Ecological Approach (Van Lier, 2003), and with the proponents of Dogme (Thornbury and Meddings, 2009)

It is clear then, that a counter-current is still alive and well. It is not however articulated into a single, unified, though multi-facetted, approach. These voices therefore tend to remain fragmented, single instances which go largely unheard except by a few devotees. Such approaches are all too often regarded as optional, 
wet-Friday-afternoon peripherals. The real change I am advocating here is to bring together the many separate threads of artistry and weave them into a seamless garment, and to make them central to what we do.

\section{How might it be done?}

Many years ago, Colin Mortimer wrote this in an undated publication of CIEFL, Hyderabad, India,

It is sometimes salutary for those of us who write...materials for language learning purposes to try to regard the restrictions under which we work ... rather in the way that a poet would regard the narrow confines of sonnet form, or the composer the rigid constraints of fugue form - that is, more as a stimulus and challenge to creative endeavour than as a justification for trite work.

He went on,

...there are lessons that poets, dramatists and novelists can teach us about how to put words together which... will not only enhance the appeal of our materials, but will also contribute greatly to their learnability...

This is perhaps a fitting introduction to the 'how' of an aesthetic approach. Although his remarks were directed to materials writing only, the direction of his thoughts is clear. I want to suggest that there are three main ways of articulating such an aesthetic approach. These would be to set out what its content might be (the Matter), the procedures it might deploy (the Methods), and the psychological feel of it (the Manner). 


\section{The Matter}

Here I am referring to the inputs to the learning process. In an aesthetic approach, I would anticipate that the following types of artistic input would occupy a more important place:

- Visual images in the form of genuine art. These might include classical 'high' art, as well as contemporary more exploratory forms such as those promoted in recent years by the Turner Award, and images in general. (Keddie, 2009 )

- Music of all kinds, not simply the use of pop songs. Music can serve as an indirect as well as a direct stimulus to learning. Indeed it is a central component of innovative approaches such as Suggestopoedia. A wide range of instrumental, orchestral, choral and solo vocal styles would be deployed. The importance of music as a fundamental rhythmic form allied to language has of course been greatly promoted through the work of Carolyn Graham (2007), and Ben Russell (IATEFL, 2009, Conference selections) who have also worked extensively on techniques for harnessing music to the learning of the language.

- A wide range of non-referential, imaginative texts would be used, with a high proportion of figurative language, requiring representational interpretation. In short, literature in its broadest sense, including stories both for telling and for reading, ranging from authentic graded readers to classics and everything in between. The seminal work of Andrew Wright is noteworthy in this context, (Wright, 2008; Wright and Hill, 2009). There is now plenty of material for teachers to draw upon, including material for the writing of creative texts as well as for their consumption. 
(Maley and Duff, 2007). Theatre and drama, in all its aspects; voice, movement, scenery, etc. would play an important role. Drama is a uniquely powerful way of integrating all aspects of language (including non-verbal language) and of taking account of multiple intelligences (Gardner, 1985) and sensory learning preferences. (Maley and Duff, 2005; Wilson, 2009).

- Moving images in the form of film, DVD and video would form an important part of the input. The work of Barry Tomalin has shown how this might be done (Stempleski and Tomalin, 2001).

- Student-made inputs would be an integral part of the input: imaginative texts created by one group of students for use with another, artwork and books, photographs taken in the community, student videos, websites, blogs, etc. The imaginative use of living authors working with schools has been implemented in Portugal and beyond through the work of Fitch O'Connell and the British Council's BritLit project. The Children's Own Stories published by Universiti Sains Malaysia in Penang are another excellent example of what can be done in publishing children's own work for use by their peers.

\section{The Methods}

Here I am not referring to the concept of 'method' as a rigid set of procedures to be rigorously applied but rather to generic types of activity.

- Project work. The engagement of students in projects, however modest, would be a major form of activity (Fried-Booth, 2005; Burwood, Dunmore and Phillips, 1999). 
- Ensemble work. Here I am referring to shared commitment to a production of some kind - from the 'orchestration' of a poem or text by small groups (as in Reader's Theatre), to rehearsed sketches, performed stories and even full-length plays. The degree of personal and linguistic investment by students in such work is widely attested, as are the benefits of the formation of a learning community, documented in great detail in Lutzker's recent volume (2007).

- Autonomous engagement. Personal reflection, research, writing and reading (including massive quantities of Extensive Reading) would be an essential methodological tool. (Krashen, 2004; Day and Bamford, 1998) We know that most useful learning takes place outside the classroom, not in. This kind of work would be capitalizing on notions of 'deep processing' (Craik and Lockhart, 1972).

- Multi-dimensional activities. Activities involving not just language skills and thinking but also movement, physical engagement through the eyes, the nose, the taste buds, hearing and touch, and tapping into memory, visualization and dreams would form an important component (Tomlinson 1998, pp.265-278).

- Problem-solving. The aim would be to make much of the learning discovery-centred rather than telling-centred. This also links with the 'deep processing' idea mentioned above.

- Playfulness. Activities would always be designed with a playful element, not simply because they would be more enjoyable but also because play is a major factor in learning anything (Crystal 1998). 


\section{The Manner}

In describing below what I feel to be essential qualities of the way in which teachers demonstrate their artistry, I am aware of the dangers of seemingly naïve and 'woolly' self-indulgence. Yet, as those of us know who have the experience of entering other teachers' classrooms, the tone or atmosphere of the class is immediately palpable. There is a 'something in the air', even if it is silence, which tells us about the quality of what is going on. For me, it is a central task for the teacher to create that enabling atmosphere, without which no enduring learning takes place.

- Atmosphere and Flow. I referred earlier to Csikszentmihalyi's work on 'flow'. Flow experiences are characterized by a kind of timeless quality where the participants are so absorbed in the activity of the moment that they lose all sense of the passage of time, of themselves, of anything outside it. They are lost in the action, just as we can become lost in a good book. In an aesthetic view of learning, it is the teacher's prime task to set up an atmosphere which facilitates flow.

- Openness, experiment and risk. Also key to the manner is the establishment of an attitude of openness: to the language, to the learning process itself, to others in the group and to oneself. In such a psychological environment, there is encouragement of experimentation and risk-taking, in the confidence that there will be mutual support, whatever the outcome. Lutzker has insightfully compared the state of unknowingness of the clown with that of the teacher in this kind of classroom: 
It is the clown's complete lack of knowledge of what will happen, coupled with his complete openness and receptivity to what is occurring on stage, which exemplifies that state of attentiveness upon which creative and fluid response in a classroom are also based. Lutzker, 2007, p.184)

This is similar to the state described by Underhill (2009),

Working with what comes requires continually learning my way into each present moment as it cascades in.

- Choice. The opportunity to make choices also contributes to the overall quality of the learning. This is not to say that learners do just what they like, when they like. Choice implies responsibility and discipline but this is best established voluntarily, from within, rather than imposed from without. Students might decide on a particular project, and on how to go about it, on the understanding that the outcomes and consequences are their responsibility. The important thing is to offer choice whenever it is an option.

- Mutual trust and support. Errors or perceived lack of success are not tarred with the brush of blame. The manner in which the class operates ensures that people support each other, recognising that everyone needs other people at some time.

\section{Concluding remarks}

This paper has been an extended inquiry into what education is and should be. There are essentially two main conceptions of education. One of them views education as a natural process which can be guided but not controlled. The 
function of the teacher in such a view, is to act as a Vygotskian scaffolder. The other views education as an institutionalised process which can (indeed must) have predetermined outcomes. The function of the teacher in this view is to act as a technician ensuring that the 'delivery systems' function. I have suggested that we need to move closer to the former view of education.

I am aware that what I am proposing here may sound fanciful and unworkable in a world governed by measurement, graded objectives and the like. However, I persist in the belief, based on over 45 years of experience, that it is the quality of the learning experience that ultimately counts, not the technicity. And that a texture of learning permeated by the art of its inputs and methods and by the artistry of its teachers is best calculated to offer that quality.

It can often seem futile to criticise the 'status quo' in the way I have been doing in this paper. After all, this is the way things are. What can we do about it? You cannot swim against the tide... I believe however that it is possible to do something to remedy the sad state of affairs in education which I have been critiquing. To accept things as they are, in the belief that they are immutable, should not be an option, and there are countless examples of cases where the apparently unchangeable has changed or been changed. The fall of the Berlin Wall is not a bad example! The success of Mahatma Gandhi in ending British rule in India is another. The emancipation of women is another. The release of Nelson Mandela yet another. It is possible to raise awareness of the insane direction education (and society at large) is taking. And it is possible, in however small a 
way, to practice an aesthetic approach to what we do. We are not powerless. We can effect change.

All that is necessary for the triumph of evil is for good men (sic) to do nothing. (Edmund Burke) 


\section{References}

Allport, G. (1983). Becoming: Basic considerations for a psychology of personality. New Haven: Yale University Press.

Arnold, J. (1999). Affect in language learning. Cambridge: Cambridge University Press.

Ashton-Warner, S. (1986). Teacher. London: Touchstone.

Bruner, J. (1991). The process of education. Cambridge Mass: Harvard University Press.

Bruner, J. (1996). The culture of education. Cambridge, Mass: Harvard University Press.

Burwood, S., Dunford, H., and Phillips, D. (1999). Projects with young learners. Oxford: Oxford University Press.

Carter, R. (2004). The art of common talk. London: Routledge.

Cook, G. (2000). Language play: Language learning. Oxford: Oxford University Press.

Craik, F.I.M. and Lockhart, R.S. (1972). Levels of processing: a framework for memory research. Journal for Verbal Learning and Verbal Behaviour II: 617-84.

Crystal, D. (1998). Language play. London: Penguin Books.

Csikszentmihalyi, M. (1990). Flow: The psychology of optimal experience. New York: Harper Row.

Csikszentmihalyi, M. (1996). Creativity: Flow and the psychology of discovery and invention. New York: Harper Perennial.

Davis, P. and Rinvolucri, M. (1988). Dictation: New methods, new possibilities. Cambridge: Cambridge University Press.

Day, R. and Bamford, J. (1998). Extensive reading in the second language classroom. Cambridge: Cambridge University Press.

Dewey, J. (1980). Art as experience. New York: Putnam's Sons.

Dufeu, B. (1994). Teaching myself. Oxford: Oxford University Press.

Eisner, E.W. (1985). The educational imagination: On the design and evaluation of school programs. New York: Macmillan.

Eisner, E.W. (2002). The arts and the creation of mind. New Haven: Yale UP.

Freeman, D. (2000). Telling teaching and the dilemma of doing, in <hltmag.co.uk $>$ Year 2, Issue 1, Jan. 2000.

Freire, P. (1970). Pedagogy of the oppressed. New York: Continuum.

Fried, B. (2006). Project work, $2^{\text {nd }}$ edition. Oxford: Oxford University Press.

Fulghum, R. (1986). All I really need to know I learned in kindergarten. London: Grafton Books.

Gallwey, T. (1986). The inner game of tennis. London: Pan books.

Gardner, H. (1985). Frames of mind. London: Paladin/Granada.

Goleman, D. (1996). Emotional intelligence. London: Bloomsbury publishing.

Goodman, P. (1966). Compulsory mis-education. New York: Random House.

Graham, C. (2007). Creating songs and chants. Oxford: Oxford University Press. 
Hadfield, J. (1992). Classroom dynamics. Oxford: Oxford University Press.

Holt, J. (1964). How children fail. New York: Pitman Publishing.

Huizinga, J. (1938/1955). Homo Ludens: A study of the play element in culture. Boston: Beacon Press.

Hunfeld, H. (1990). Litaratur als sprachlehre: Ansatze eines hermeneutisch orientierten Fremdsprachen-unterrichts. Berlin: Langenscheidt.

Illich, I. (1973). De-schooling society. London: Penguin.

James, W. (1962). Talks to teachers on psychology and to students on some of life's ideals. New York: Henry Holt 1899 reprint. Mineola, N.Y: Dover.

Jakobson, R. (1960). Closing Statements: Linguistics and Poetics. In T. Sebeok (ed.). Style in language (pp.350-377). Cambridge MA: MIT Press.

Jespersen, O. (1904). How to teach a foreign language. London: Allen and Unwin.

Keddie, J. (2009). Images. Oxford: Oxford University Press.

Koestler, A. (1964). The act of creation. London: Penguin Books.

Krashen, S. (2004). The power of reading: Insights from the research (2 ${ }^{\text {nd }}$ edition). Portsmouth NH: Heinemann

Lutzker, P. (2007). The art of foreign language teaching. Tubingen und Basel: Francke Verlag.

Maley, A. (2000). The language teacher's voice. Oxford: Heinemann/Macmillan.

Maley, A. and Duff, A. (2005). Drama techniques. Cambridge: Cambridge University Press.

Maley, A. (2003). Inputs, processes and outcomes in materials development: Extending the range. In J. Mukundan (ed.). Readings on ELT Material. Serdang: Universiti Putra Malaysia Press.

Maley, A. (2006). Swimming against the tide. In J. Mukundan (ed.). ELT Matters 3. Serdang: Universiti Putra Malaysia Press.

Marshall, S. (1970). An experiment in education. Cambridge: Cambridge University Press.

Mortimer, C. (undated, c 1970). The dramatic-implicatory component. Hyderabad /CIEFL

Nachmanovitch, S. (1990). Free play: Improvisation in life and art. New York: Tarcher/Putnam/Penguin.

Palmer, P.J. (1998). The courage to teach: Exploring the inner landscape of a teacher's life. San Francisco: Jossey-Bass.

Postman, N. (1992). Technopoly: The surrender of culture to technology. New York: Alfred A. Knopf.

Postman, N. and Weingartner, C. (1976). Teaching as a subversive activity. Harmondsworth: Penguin Books.

Puchta, H. and Rinvolucri, M. (2005) Multiple intelligences in EFL. Innsbruck: Helbling Languages.

Reimer, E. (1972). School is dead. New York: Anchor Books. 
Richards, J.C. and Rodgers T.S. (2001). Approaches and methods in language teaching $\left(2^{\text {nd }}\right.$ edition) (pp.192-203). Cambridge: Cambridge University Press.

Rinvolucri, M. (see Davis and Rinvolucri 1988, Puchta and Rinvolucri 2005, above.)

Rodenburg, P. (1992). The right to speak: Working with the voice. London: Methuen.

Russell, B. (2009). Report on the Symposium on the Art and Artistry of ELT. IATEFL 2009 Cardiff, Conference Selections. Canterbury: IATEFL.

Rogers, C. (1969). Freedom to learn. Columbus: Charles Merrill and Co.

Rubin, L.J. (1985). Artistry in teaching. New York: Random House.

Sarason, S.B. (1999). Teaching as a performing art. New York: Teachers' College Press.

Schon, D. (1987). The reflective practitioner: How professionals think in action. San Francisco: Jossey-Bass/Wiley.

Stempleski, S. and Tomalin, B. (2001). Film. Oxford: Oxford University Press.

Stevick, E. (1980). Teaching languages: A way and ways. Rowley, MA: Newbury House.

Storr, A. (1991). The dynamics of creation. London: Penguin Books.

Thornbury, S and Meddings, L. (2009). Teaching unplugged. London: Delta publications.

Tomlinson, B. (ed.). (1998). Materials development in language teaching. Cambridge: Cambridge University Press.

Tomlinson, B. (ed.). (2003). Developing materials for language teaching. London/New York: Continuum.

Underhill, A. (2008). Work with what comes. In Teacher development newsletter. Issue 59, Winter 2008. Canterbury: IATEFL.

van Lier, L. (2003). A tale of two computer classrooms: The ecology of project-based language learning. In J. van Dam and J. Leather (eds.). The ecology of language acquisition (pp. 49-64). Dordrecht: Kluwer Academic.

Wagner, B.J. (1979). Dorothy Heathcote: Drama as a learning medium. London: Hutchinson.

Widdowson, H.G. (2000). Teaching as an art. The Journal of the Imagination in Language Learning and Teaching. (available online at http://www.njcu.edu/cill/vol5/widdowson.html )

Wilson, K. (2009). Drama and improvisation. Oxford : Oxford University Press.

Wittgenstein, L. (1963). Philosophical investigations. Oxford: Basil Blackwell.

Wright, A. (2008). Storytelling with children ( $2^{\text {nd }}$ ed.). Oxford: Oxford University Press.

Wright, A. and Hill, D.A. (2009). Writing stories. Innsbruck: Helbling. 